\title{
Adulteration and Bacterial Contamination of Locally Processed Honeys Marketed at Lafia Metropolis, Nasarawa State, Nigeria
}

\author{
Y. Ya'aba ${ }^{*, 1,2}$, U. S. Okposhi', D. D. Odonye ${ }^{2}$ and A. S. Ramalan ${ }^{2}$ \\ ${ }^{1}$ Department of Microbiology and Biotechnology, National Institute for Pharmaceutical \\ Research and Development (NIPRD) Abuja, Nigeria \\ ${ }^{2}$ Department of Microbiology, Federal University of Lafia, Nasarawa State, Nigeria \\ *Corresponding author
}

\section{A B S T R A C T}

\begin{tabular}{|l|}
\hline Ke y w o r d s \\
Honey, Bacterial \\
quality, Retail \\
outlets, \\
Microbiological \\
techniques, Lafia \\
metropolis, \\
Bacillus sp.
\end{tabular}

Honey is used for nutritional, medicinal and industrial purposes. The bacterial quality of honey from different retail outlets in Lafia metropolis was evaluated using standard microbiological techniques. Twenty-four honey samples were purchased, labeled and total anaerobic bacterial count determined. The samples presented different level of bacteriological contamination. The total anaerobic bacterial count for the samples ranged from $3.3 \times 10^{2}$ to $1.3 \times 10^{3} \mathrm{cfu} / \mathrm{mL}$. Bacteria isolated from the honey samples included Bacillus sp., Staphylococcus sp., Micrococcus sp., Streptococcus sp., and Escherichia sp. The most predominate $(47.83 \%)$ bacteria isolated were Bacillus sp. There was no noticeable coliform and Salmonella sp. growths in the 24 samples purchased. The variation in bacteria load and species at the various retail outlets and absence of bacteria growth in two retail outlets ( $\mathrm{H} 12$ and $\mathrm{H} 20)$ is an indication of the processing practice, totally free of any form of adulteration and as well as good hygienic condition at these outlets. However, the presence of these bacteria species in some samples might be attributed to some level of adulteration or poor handling at harvesting, packaging or storage. Therefore, may be cause for concern as these pathogenic strains of the microbes can be of serious public healthcare challenge.

\section{Introduction}

Honey is the constituent produced by honeybees as soon as nectar and sweet deposits from plants such as nectaries of flowers are assembled, improved and stored in the honey comb by honeybees (Apis melifera) to matured (Martins et al., 2001; Adebiyi et al, 2004). Natural honey is one of the most extensively wanted products owing to its unique nutritive and therapeutic properties, which are ascribed to the encouragement of the different groups of constituents it encompasses (Buba et al., 2013). Honey is fundamentally composed of a composite mixture of carbohydrates majorly of sugars $(70-80 \%)$ such as sucrose, fructose, glucose and other minor constituents, such as amino acids, proteins, organic acids, lipids minerals and vitamins (Saxena et al., 2010). 
As a contemporary agent, honey has been used since earliest times not only as food but has abundant uses and purposeful applications universally such as in spiritual and charmed ceremonies as well as in anthropological and veterinary medication (Joseph et al., 2007). Honey has been also credited for numerous biological and healing purposes such as: treatment of colds, various gastrointestinal diseases and skin wounds. This useful role is ascribed to both the anti-inflammatory and antimicrobial properties of honey that ascend from its composite mixture (Amril and Ladjama, 2013). It also has debriding and cleansing accomplishment and performances as a barricade to avoid infection. Its antimicrobial resources as a contemporary agent has been pronounced and recognized both in in vitro and in vivo research works. The evidence supports its practicality in wound healing, battling periodic allergies and infections, cough action and as an antibacterial agent (Cooper et al., 2002; Davis, 2005; Nordqvist, 2015).

Honey is not hygienic, it is characterised by low moistness and high sugar content which guarantees low proliferation of microbes (Serena et al., 2011). However, it could be associated with some incompatible health effects predominantly when it is contaminated or quality is truncated. The menaces being contaminated with moulds and other microbes from the numerous extraction and filtration approaches has also been documented for long time ago (Tysset and Rousseau, 1981). Although, due to the natural resources of honey and regulator measures in the honey industry, honey is a product with negligible types and levels of microbes (Ayansola and Adedoyin, 2012). Most honeys are supersaturated solutions of fructose and glucose with truncated $\mathrm{pH}$ sandwiched between 3.2 and 4.5. This moderately acidic $\mathrm{pH}$ level avoids the growth of several bacteria (Kebede et al., 2012).
Regardless of the usefulness of honey and its constituents, it is a key victim of adulteration, modifications in its composition and coupled with the manifestation of natural organisms, it is unsuitable for consumption for newborns and progenies who lack a fully established immunological system and are susceptible to alimentary infections (Codex Alimentarius, 2001).

The microbes found in honey originate from the nectar and pollen, from the processing neighborhood, apparatuses and vessels that are not properly washed (Popa et al., 2010). These microbes found are those that can withstand high sugar content, acidity and antimicrobial resources of honey, they include certain spore- forming bacteria and yeast. Yeast existing in honey could cause fermentation thereby resulting in development of alcohol and carbon dioxide $\left(\mathrm{CO}_{2}\right)$, the alcohol additional gets oxidized into other compounds such as acetic acid in the presence of oxygen $\left(\mathrm{O}_{2}\right)$, consequently, producing the sour taste of honey (Agbagwa et al., 2011). Bacteriological load contamination during and or post processing can also result in breakdown or perseverance of some bacteria in honey (Tchoumboue et al., 2007).

Adulteration of honey is probably not an uncommon practice in this part of the country in early 80 's. This practice is fraudulent as it is not easily detectable and very undesirable to consumers; henceforth the prevalence of this practice is an indispensable knowledge. It is also very possible that this practice has a relationship with the safety of the final commercially obtainable product. In view of this, there is the need to evaluate the authenticity and biosafety (bacteriologically) of commercially obtainable honey.

Honey has been produced in Lafia local government area of Nasarawa State, Nigeria for a longtime but data relating to the 
adulteration and bacteria contamination is limited. There is apparent nonexistence of consumer self-assurance due to alleged adulteration consequently fewer patronage to this enormously appreciated the product. Worse still is regardless of the high cost of honey, consumers are cheated through adulteration and other modification by the retailers. These complications are the motivating force for this research work. Therefore, this research work is aimed at determining the bacterial load contamination of some locally available honey in Lafia, Nasarawa State, Nigeria.

\section{Materials and Methods}

\section{Research Location}

This research was carried out at Lafia. Lafia is a local government headquarter and the state capital of Nasarawa state, Nigeria. It is situated in the North central part of Nigeria lying at latitude $8^{\circ} 29^{\prime} 30^{\prime}$ ' North of the equator and longitude $8^{\circ} 31^{\prime} 0^{\prime}$ 'East of Greenwich Meridian. Lafia has a total inhabitant of 330, 712 (NPC, 2006; Akwa et $a l ., 2007)$ and it is recently reported to have population of 127, 236 (WPR, 2019).

\section{Sample Collection}

A total of twenty-four (24) natural honey samples were randomly selected and purchased in July 2019 from different retail outlets across the Lafia metropolis. They were transported at room temperature in sterile containers for bacteriological analysis at the Microbiology Laboratory of the Department of Microbiology all of the Federal University of Lafia.

\section{Bacteriological Analysis}

The bacteriological analysis was performed using the method described by Agbagwa et al., (2011). The viable cell count of samples was determined by carrying out serial dilutions of the stock solution of each honey sample to obtain dilutions of $10^{1}-10^{4}$. That is, $10 \mathrm{~mL}$ of each honey sample was measured and transferred aseptically into $90 \mathrm{~mL}$ of $0.1 \%$ sterile peptone water to form the stock solution. Approximately, $1 \mathrm{~mL}$ of each stock solution was transferred into $9 \mathrm{~mL}$ of $0.1 \%$ sterile peptone water $\left(10^{1}\right)$ and this was serially diluted until $10^{4}$ dilutions were obtained. A solution of $0.1 \mathrm{~mL}$ of $10^{4}$ dilution was then aseptically transferred into sterile plate count agar (PCA) and MacCkonkey agar (MAC) for bacterial and coliform count.

A sterile bent glass rod was used to spread the inocula (diluted sample) on the surface of the culture media. The inoculated plates were then incubated at $37^{\circ} \mathrm{C}$ for $24 \mathrm{hrs}$. Plate count agar and MacConkey agar plates for bacteria and coliform counts respectively.

After the incubation period of $24 \mathrm{hrs}$ at $37^{\circ} \mathrm{C}$, the number of the bacteria colonies growth were then counted using a colony counter and the results were documented and expressed as colony forming unit per milliliter (CFU/ML) of the sample using equation

$\mathrm{CFU} / \mathrm{ML}=\underline{\text { Total number of colonies counted }}$ $\underline{x}$ Dilution factor

Volume of inocula

\section{Gram's staining, Morphological and Biochemical characterization of bacteria}

Gram staining was done for each isolate according to standard procedure for the differentiation of gram-positive bacteria from gram-negative bacteria as described by Duncan et al., 2005. Microscopic examination was done for each isolate gram stained to observe their shape and cellular arrangement as described by Duncan et al., 2005. 
The pure bacterial colonies isolated were characterized as described by Omafuvbe and Akanbi, (2009) using colonial, microscopic and biochemical characteristics (catalase test, indole production test, Voges-Proskauer (VP)- reactive compound test, Methyl redreactive compounds test, citrate utilization test, oxidase test). All tests were carried out using standard basic media and reagents (Atlas, 1997) and prepared as described by manufacturer's procedure. The isolates were identified following a check on their characteristics which matched those of existing taxa in standard manuals. Characteristics of bacteria in Bergy's Manual of determinative bacteriology were used as a standard in this case. Isolates were thus identified in line with those contained in the manual and were named according to their matching species.

The biochemical tests carried out on the bacteria isolates as described by Omafuvbe and Akanbi, (2009) are briefly discussed below:

\section{Catalase}

This test was carried out on isolates obtained from the culture on mannitol salt agar to confirm the presence of Staphylococcus species. A loopful of $10 \% \mathrm{~V} / \mathrm{V}$ hydrogen peroxide $\left(\mathrm{H}_{2} \mathrm{O}_{2}\right)$ solution was placed on a clean grease free slide. Using a sterile glass rod, a sample of the test organism was transferred to a liquid of hydrogen peroxide. An immediate bubbling indicated the production of catalase while lack of bubble formation showed a catalase negative result.

\section{Indole production test}

This was done on suspected overnight broth culture. A volume of $2 \mathrm{ml}$ of the broth was tipped into a test tube and 5 drops of the Kovac's reagent was added and gently swirled. The formation of bright pink colour at the inter-phase of the broth and the reagent in the tube within seconds indicated indole positive test.

\section{Voges-Proskauer (VP)-reactive compounds}

A tube of broth culture was inoculated and incubated at $48 \pm 2 \mathrm{~h}$ at $35^{\circ} \mathrm{C}$. $1 \mathrm{ml}$ of the culture was transferred to $13 \times 100 \mathrm{~mm}$ tube. $0.6 \mathrm{ml} \propto$-naphthol solution and $0.2 \mathrm{ml} 40 \%$ $\mathrm{KOH}$ were added, and shaken. A few crystals of creatine were added, shaken and let to stand for 2 hours. Test was positive if eosin pink color developed.

\section{Methyl red-reactive compounds}

After VP test, incubation of the broth tube for an additional $48 \pm 2 \mathrm{~h}$ at $35^{\circ} \mathrm{C}$ was done. Five drops of methyl red solution were added to each tube. Distinct red color indicated a positive test. Yellow indicated a negative reaction.

\section{Citrate utilization test}

This was carried out by inoculating the suspected organism onto Simmon's citrate agar slope with straight wire. The inoculated agar slope was then incubated at $37^{\circ} \mathrm{C}$ for a period of 24 hours. A change in the original green colour to a deep blue colour indicated positive test.

\section{Oxidase test}

This test was used to check for the presence of the enzyme indophenol oxidase. Tetramethyl-para-phenylenediamine (oxidase reagent) was oxidized by oxidase-positive organisms in the presence of atmospheric oxygen by indophenol oxidase causing the formation of a dark-purple compound known as indophenol. 


\section{Statistical Analyses}

The quantitative data were analyzed statistically using SPSS (version 20) statistical software. Standard descriptive statistics such as percentages were used to describe some of the findings in tabular form.

\section{Results and Discussion}

Bacterial plate counts for the 24 honey samples ranged from $3.3 \times 10^{2}$ to $1.3 \times 10^{3}$ $\mathrm{cfu} / \mathrm{mL}$ of honey is shown in Table 1 . Six samples $(25.0 \%)$ yielded total aerobic bacteria count of $3.3 \times 10^{2} \mathrm{cfu} / \mathrm{mL}$, nine samples (37.5\%) yielded $6.7 \times 10^{2} \mathrm{cfu} / \mathrm{mL}$, six samples (25.0\%) yielded $1.0 \times 10^{3} \mathrm{cfu} / \mathrm{mL}$, one sample (4.2\%) yielded $1.3 \times 10^{3} \mathrm{cfu} / \mathrm{mL}$ while two samples $(8.3 \%)$ no growth was observed respectively.

A total of forty-six (46) isolates were obtained from the twenty-four samples test. The morphological and biochemical characteristics of the isolates obtained from the honey samples collected in Lafia metropolis are shown in Table 2. Twenty-two $(47.83 \%)$ of the isolates obtained are large rods appearing in chains, endospore formers, catalase-positive, gram-positive rods fermenting glucose and are identified to be Bacillus species.

Three $(6.52 \%)$ of the fourteen isolates that were catalase-positive, gram-positive cocci appearing in clusters, were oxidase-positive and were not able to utilize glucose and show significant growth on mannitol salt agar and are thus identified as Micrococcus species. The other eleven isolates $(23.91 \%)$ that were catalase-positive, gram-positive cocci appearing in clusters, are oxidase-negative, halophilic, producing acid on mannitol salt agar and could ferment glucose. They are therefore identified as Staphylococcus species.
All of the three $(6.52 \%)$ isolates that were catalase-negative gram-positive cocci, were oxidase-negative, glucose-fermenting organisms and are identified as Streptococcus species.

All of the seven $(15.22 \%)$ isolates that were catalase-positive gram-negative rods were positive to both Indole test and Methyl Red test and were negative to Voges-Proskauer and Citrate test and hence had an IMViC pattern of (++--) and were identified as Escherichia species.

The preliminary bacteria identification (Table 3 ) shows that, of the forty-six (46) isolates obtained, twenty-two (22) were catalasepositive, gram-positive rods, fourteen (14) were catalase-positive gram-positive cocci, three (3) were catalase-negative gram-positive cocci, and seven (7) were catalase-positive gram-negative rods.

A total of five (5) genera were identified from the isolates; these include Bacillus, Staphylococcus, Micrococcus, Streptococcus and Escherichia. The distributions of the identified isolates are shown in Table 4. Bacillus species constituted $47.83 \%$ of the total number of isolates obtained from the 46 of the organisms isolated from the samples during the research work. The distribution of Micrococcus and Streptococcus species is even, each making up $6.52 \%$ of the total number of isolates; Escherichia species constituted $15.22 \%$ of the isolates obtained during the research work.

The bacteria isolated from honey samples from different retail outlets in this research work (Table 1) revealed the presence of bacteria to include Bacillus sp., Staphylococcus sp., Micrococcus sp., Streptococcus sp., and Escherichia sp. This is in agreement with previous research work done by Onyeze et al., (2013) in which 
Staphylococcus sp., Micrococcus sp., Escherichia coli and Enterobacter sp., were isolated from honey in three different districts in Enugu State in Nigeria. The result is also similar to the findings of Al-Hindi, (2003) who in their studies found that honey pastes were contaminated with Bacillus sp., Micrococcus sp., Staphylococcus sp., Aerobacter sp., Clostridium sp., Streptococcus sp., and Enterococcus sp., in Jeddah, Saudi Arabia.

The bacteriological analysis of the honey samples from various retail outlets in this research work revealed that there was no coliform and Salmonella sp. growths in the 24 samples purchased. This is an indication of the sanitary quality of the honey. This is similar to study done by other scientists who reported that total coliform was not detected in honey (Rall et al., 2003; Iurlina and Fritz, 2005; Malika et al., 2005).

In this work, the total aerobic bacteria count (TABC) in the samples ranged from $3.3 \times 10^{2}$ $-1.3 \times 10^{3} \mathrm{cfu} / \mathrm{mL}$. Our result on total aerobic bacteria counts is lower than that reported by Iurlina and Fritz (2005) and Malika et al., (2005) but falls within the range reported by Tysset and Roussean (1981).

Table.1 Total Aerobic Bacterial Counts in the honey samples in Lafia

\begin{tabular}{|c|c|}
\hline $\begin{array}{c}\text { Sample } \\
\text { ID }\end{array}$ & $\begin{array}{c}\text { Total Aerobic Bacteria } \\
\text { Count (CFU/ML) }\end{array}$ \\
\hline H1 & $6.7 \times 10^{2}$ \\
\hline H2 & $1.0 \times 10^{3}$ \\
\hline H3 & $3.3 \times 10^{2}$ \\
\hline H4 & $1.3 \times 10^{3}$ \\
\hline H5 & $6.7 \times 10^{2}$ \\
\hline H6 & $6.7 \times 10^{2}$ \\
\hline H7 & $6.7 \times 10^{2}$ \\
\hline H8 & $1.0 \times 10^{3}$ \\
\hline H9 & $6.7 \times 10^{2}$ \\
\hline H10 & $3.3 \times 10^{2}$ \\
\hline H11 & $1.0 \times 10^{3}$ \\
\hline H12 & Absent \\
\hline H13 & $3.3 \times 10^{2}$ \\
\hline H14 & $6.7 \times 10^{2}$ \\
\hline H15 & $1.0 \times 10^{3}$ \\
\hline H16 & $6.7 \times 10^{2}$ \\
\hline H17 & $6.7 \times 10^{2}$ \\
\hline H18 & $3.3 \times 10^{2}$ \\
\hline H19 & $3.3 \times 10^{2}$ \\
\hline H20 & Absent \\
\hline H21 & $6.7 \times 10^{2}$ \\
\hline H22 & $3.3 \times 10^{2}$ \\
\hline H23 & $1.0 \times 10^{3}$ \\
\hline H24 & $1.0 \times 10^{3}$ \\
\hline
\end{tabular}


Table.2 Morphological and biochemical characteristics of isolates

\begin{tabular}{|c|c|c|c|c|c|}
\hline Morphology & $\begin{array}{l}\text { Cocci in } \\
\text { clusters }\end{array}$ & $\begin{array}{l}\text { Cocci in small } \\
\text { clusters }\end{array}$ & Cocci in chains & $\begin{array}{l}\text { Large rods } \\
\text { in chains }\end{array}$ & Short rods \\
\hline Gram reaction & + & + & + & + & - \\
\hline Catalase reaction & + & + & - & + & + \\
\hline Endospores & - & - & - & + & - \\
\hline Oxidase reaction & - & + & - & + & - \\
\hline Glucose fermentation & + & - & + & + & + \\
\hline $\begin{array}{c}\text { Growth on Mannitol } \\
\text { Salt Agar }\end{array}$ & $\begin{array}{l}+/ \text { Acid } \\
\text { produced }\end{array}$ & - & - & N/A & N/A \\
\hline $\begin{array}{c}\text { Growth on McConkey } \\
\text { Agar }\end{array}$ & N/A & N/A & N/A & - & $\begin{array}{l}+/ \text { Acid } \\
\text { produced }\end{array}$ \\
\hline Indole & N/A & N/A & N/A & N/A & + \\
\hline Methyl Red & N/A & & & & + \\
\hline Voges-Proskauer & N/A & N/A & N/A & N/A & - \\
\hline Citrate Utilisation & N/A & N/A & N/A & N/A & - \\
\hline Most Probable Genus & Staphylococcus & Micrococcus & Streptococcus & Bacillus & Escherichia \\
\hline Number of Isolates & 11 & 3 & 3 & 22 & 7 \\
\hline
\end{tabular}

Key: (+) positive (-) negative (N/A) - Not Applicable

Table.3 Preliminary Bacteria Identification

\begin{tabular}{|c|c|c|c|c|}
\hline Reaction & \multicolumn{2}{|c|}{ Gram-positive bacteria } & \multicolumn{2}{c|}{ Gram-negative bacteria } \\
\hline & Rods & Cocci & Rods & Cocci \\
\hline Catalase (+) & 22 & 14 & 7 & Nil \\
\hline Catalase (-) & Nil & 3 & Nil & Nil \\
\hline
\end{tabular}

Key: (+) positive (-) negative

Table.4 Distribution of the identified isolates Bacterial Contaminants of Honey Samples

\begin{tabular}{|c|c|c|}
\hline Bacteria Isolates & No. of Isolates & Percentage (\%) \\
\hline Bacillus sp. & 22 & 47.83 \\
\hline Staphylococcus sp. & 11 & 23.91 \\
\hline Micrococcus sp. & 3 & 6.52 \\
\hline Streptococcus sp. & 3 & 6.52 \\
\hline Escherichia sp. & 7 & 15.22 \\
\hline Total & 46 & 100.00 \\
\hline
\end{tabular}

This disparity in total aerobic bacteria counts may be due to the type of sample, freshness of the honey, the period of harvest and the investigative methods used (Snowdon and Cliver, 1996). However, this does not necessarily indicate adulteration or contamination but micro flora associated with honey. When the counts surpass a particular level, it can then be proposed that the honey is adulterated, which can lead to increase in 
bacterial counts. Although, it was reported by Lawal et al., (2009) that the adulteration of Nigerian honey may be due to unhygienic handling during processing and storage.

The existence of this bacteria isolates from this research work (Table 1) may be also ascribed to the extraction, unhygienic handling and processing of the honey product. In some of the retail outlets, persons were seen carrying the products in unsanitary plastic containers and bottles on their head and in their hand. Thus, exposing the product to unhygienic environmental condition and most at times these containers are not well covered to prevent flies and other microbes from setting on it, thereby creating avenue for its contamination with microorganisms. Although, it was earlier reported that contamination from skin, mouth and even nose of food handlers can be introduced directly into food during processing and other activities by retailers and distributors before final consumption by the consumers (Voula et al., 2013). The primary source of honey contamination includes the digestive tracts of honeybees, pollen, nectar, dust and air which have challenges to be controlled. While, others like honey handlers, cross contamination, equipment's and buildings are secondary sources which can be controlled by Good Manufacturing Practices (GMP) (Kacaniova et al., 2012). However, some researchers documented that bacteria and fungi contamination is an indication of inadequate hygienic conditions of collecting, processing, manipulating and storing. Microbiological quality of the honey may serve as an indicator of the hygienic conditions under which the honey was processed, handled and stored (Ayansola and Banjo, 2002).

The results obtained for all the honeys are mostly of good quality and acceptable when compared with Codex Alimentarius (2001) honey specifications, since highest total aerobic bacteria count recorded was $1.3 \times 10^{3}$ $\mathrm{cfu} / \mathrm{mL}$ which falls within the acceptable limit of $1.0 \times 10^{4} \mathrm{cfu} / \mathrm{mL}$. Nevertheless, honey is a relatively poor medium for the growth of bacteria it is not to be considered sterile (Sereia et al., 2011), therefore the detection of some aerobic organisms is not viewed as strange phenomenon. Some authors have showed that total aerobic bacteria viable count in honey can vary between zero and tens of thousands per millitres. For instance, Iurlina and Fritz (2005) in their studies analysed seventy honey samples from different parts of Argentina and found the total viable count of aerobic bacteria of $1.0 \mathrm{x}$ $10^{3} \mathrm{cfu} / \mathrm{mL}$ in each of the samples analysed. Similarly, Kn̆azovická et al., (2009) also reported a mean value of $1.4 \times 10^{2} \mathrm{cfu} / \mathrm{mL}$ of aerobic bacteria isolated from honey. According to Omafuvbe and Akanabi (2009), the mean number of aerobic bacteria in honey ranged from $1.0 \times 10^{3}$ to $5.0 \times 10^{3} \mathrm{cfu} / \mathrm{mL}$.

Escherichia coli in the honey samples were used as pointer for human and environmental contamination. It is usually the commonest and thus most abundant pathogen in foods. Hence, its nonappearance from the honey samples gives confidence to their quality. The presence of Bacillus sp. and Streptococcus sp. in the honey samples could be owed to the ability of these aerobic microbes to form spores and thus survive in harsh conditions even as persist in honey (Laaberi and Daworkin, 2008). This goes to confirm that honey is not absolutely sterile as seen in this study; hence precautions must be taken to ensure that bacteriological contamination of honey is reduced to the barest minimum.

Disparity in bacteria load and species in the honey sample (H1- H24) at different retail outlets (Table 1) may be due to disparity in the processing and handling of the product at these outlets. The nonappearance of bacteria growth in sample (H12 and H20) from two 
retail outlet also supports this fact. It may be found that retailers at these 2 outlets had special training in apiaries and thus, done handling and other activities under good hygienic conditions of all forms. Honeys that are well preserved provide uncomplimentary conditions for bacteria to live (Adenekan et al., 2010).

In conclusion the bacteriological analysis of the honey samples from various retailer outlets revealed that samples $\mathrm{H} 12$ and $\mathrm{H} 20$ were totally free of any form of adulteration. This is made known by the absence of coliform, salmonella $\mathrm{sp}$ and total aerobic bacteria counts. However, other samples might undergo some level of adulteration or may be attributed to poor handling at harvesting, packaging or storage, thus the presence of total aerobic bacteria counts.

\section{Recommendations}

Honey processing should be controlled and inspected by both health and standardization authorities. Based on the microbial population observed, it could be stated that such foodstuff may play a role (to some extent) as a causative agent for some food-borne illnesses. Managers and owners of plants processing honey pastes should be compelled to apply good manufacturing practices (GMP) through application of total quality programs including hazard analysis and critical control points system. Consumers should be aware when consuming locally processed honey regarding their contents.

\section{References}

Adebiyi, F., Akpan, I., Obiajunwa, E., Olaniyi, H. (2004). Chemical/Physical Characterization of Nigerian Honey. Pakistan Journal of Nutrition, 3 (5): 278281.

Adenekan, M.O., Amusa, N.A., Lawal, A.O.,
Okpeze, V.E. (2010). Physico-chemical and microbiological properties of honey samples obtained from Ibadan. $J$ Microb and Antimicrob 2: 100 - 104.

Agbagwa, K., Otokunefor, O.E., FrankPeterside, T.V., Nnenna, K. (2011). Quality assessment of Nigeria honey and manuka honey. $J$ Microbio and Biotech Res, 1: 20-31.

Al-Hindi, R.R. (2003). Microbiology qualities of imported and locally produced honey in Saudi Arabia. Arab Gulf J Sci Res, 21:204.

Akwa, V.L., Bimbol, N.L., Samaila, K.L., Macus, N.D. (2007). Geography Perspective of Nassarawa State. Onaivi Printing and Publishing Company, Keffi, Nigeria. 3-5.

Amril, A., Ladjama, A. (2013). Physicochemical chara-cterization of some multifloral honeys from honeybees Apis mellifera collected in the Algerian northeast. African Journal of Food Science, 7(7): 168 - 173.

Atlas, R.M. (1997). Principles of Microbiology, 2nd edition. WmC. Brown Publishers, Dubuque; 1997.

Ayansola, A.A., Banjo, A.D. (2002). Microbiological examination of honey marketed in Southwestern Nigeria. J Basic Appl Sci Res, 2:1701-1705.

Ayansola, A.O., Adedoyin, D.B. (2012). Physico-Chemical Evaluation of The Authenticity of Honey Marketed in Southwestern Nigeria. Journal of Basic and Applied Science Research, 1(12): 3339-3344.

Buba, F., Abubakar, G., Shugaba, A. (2013). Physico-chemical and microbiological properties of honey from North East Nigeria. Biochemistry and Analytical Biochemistry, 2:14.

Codex Alimentarius. (2001). Draft revised standard for honey (at step 10 of the codex procedure). Codex Alimentarius Commission, FAO, Rome Alinorm, 25: 
$19-26$.

Cooper, R.A., Halas, E., Molan, P.C. (2002).

The efficacy of honey in inhibiting strains of Pseudomonas aeruginosa from infected burns. J. Burn Care Rehabil, 23: 366-370.

Davis, C. (2005). The use of Australian honey in moist wound management: a report for the Rural Industries Research and Development Corporation.

Duncan, F., Walker, V., Clark, N. (2005). MBC1000L: Applied Microbiology Laboratory Manual, $4^{\text {th }}$ Ed. p. 11-38. Mosby, Baltimore.

Joseph, T., Julius, A.W., A1, F.F., Delphine, D.N., Jonnas, P., Antoine, M.Z. (2007). Afr. J. Biotechnol. 6: 9081.

Kačaniová M., Melich, M., Kňazovická, V., Haščik, P., Sudzinová, J., Pavličová, S., Čuboň, J. (2012). The indicator microorganisms' value in relation to primary contamination of honey. Lucrări stiintifice Zootehnie şi Biotehnologii, 42, 159-16.

Kebede, N., Subramanian, P.A., Mebrahtu, G. (2012). Physicochemical analysis of tigray honey: an attempt to determine major quality markers of honey. Chemical Society of Ethiopia, 26(1): 127-133.

Knazovická, V., Kacaniová, M., Melich, M., Hašcik, P., Sudzinová, J. (2009). The indicator microorganisms' value in relation to primary contamination of honey. Lucraristiintifice Zootehniesi Biotehnologii, 42: 159-163.

Laaberki, M.H., Dworkin, J. (2008). Death and survival of spore forming bacterial in the Caenorhabditiselegans intestine. Symbiosis, 46: 95-100.

Lawal, R.A., Lawal, A.K., Adekalu, J.B. (2009). Physicochemical Studies on Adultration of Honey in Nigeria. Pakistan journal of Biological Sciences, 12(15): 1080- 1084.

Iurlina, M.O., Fritz, R. (2005).
Characterization of microorganisms in Argentinean honeys from different sources. Int J Food Microbiol, 105: 297-304.

Malika, N., Mohamed, F., Chakib, E. (2005). Microbiological and physico - chemical properties of Moroccan honey. Int. J. Agric. Biol, 7(5): 773- 76.

Martins, H.M., Martins, L., Lanca, A., Bernardo, F. (2001). Microbial safety assessment of honey bees (Apis mellifera) In Proceeding Book, Micro 2001, Congresso Nacional de Microbiologia, Poroa de Varzim, Portugal. p. 146.

National Population Census (NPC). (2006). Retrieved from: "https://en.wikipedia.org/w/index.php?t itle $=$ Lafia\&oldid $=917958901$ "Centre for Disease Control and Prevention (CDC) (2015). Urinary tract infection. Archived from the original on February 2016. 10-15.

Nordqvist, J. (2015) Health benefits and uses in medicine. Omafuvbe, B., Akanbi, O.O. (2009). Microbiological and physico-chemical properties of some commercial Nigerian honey. Afr $J$ Microbiol Res 3: 891-896.

Onyeze R.C., Udeh, S.M.C., Ani, L.C., Ugwu, O.P.C. (2013). Microbiology of honey collected from three different locations in Enugu State, Nigeria. World J Pharm Res. 2:1086-1095.

Popa, M., Axinite, R., Varvara, S. (2010). Study concerning microbiological and physical- chemical characteristics of Transylvania honey, 11-13.

Rall, V.L.M., Bombo, A.J., Lopes, T.F., Carvalho, I.R., Silva, M.G. (2003). Honey consumption in the State of Sâo Paulo: a risk to human health? Anaerobe, 9: 299 - 303.

Saxena, S., Gautam, S., Sharma, A. (2010). Physical, biochemical and antioxidant properties of some Indian honeys. Food 
Chemistry, 118: 391-397.

Sereia, M.J., Alves, E.M., Toledo, V.D.A.A. D., Marchini, L.C., Faquinello, P. (2011). Microbial flora in organic honey samples of Africanized honeybees from Parana River islands. Food Science and Technology (Campinas) 31: 462-466.

Serena, M.J., Alves, E.M., Toledo, V.D.A.A.D., Marchini, L.C., Faquinello, P. (2011). Microbial flora in organic honey samples of Africanized honeybees from Parana River islands. Food Sci and Tech (Campinas), 31: 462-466.

Snowdon, J. A., Cliver, D. O. (1996). Microorganisms in honey. International Journal of Food Microbiology, 31(3): 1-26.

Tchoumboue, J.J., Awah-Ndukum, F.A., Feth, N.D., Dongock, J., Pinta, A., Mvondo, Z. (2007). Physicochemical and
Microbiological characteristics of honey from the Sudan- Guinean zone of West- Cameroon. African Journal of Biotechnology, 6(7): 908-913.

Tysset, C., Rousseau, M. (1981). Problem of microbes and hygiene of commercial honey. Rev Med Vet. 132: 591-600.

Voula, A., Effie, T., Konstantinos, P., Wilhelm, H. (2013). Food Agriculture Organisation report 2013: Status and trends of the conservation and sustainable use of Microorganism in food processes. Food Agriculture organization;2013.

World Population Review (WPR) (2019). Population of Cities in Nigeria. Retrieved from: https://worldpopulationreview.com/cou ntries/nigeriapopulation/cities/.Tuesday , 15/10/2019: 21; 18

\section{How to cite this article:}

Ya'aba, Y., U. S. Okposhi, D. D. Odonye and Ramalan, A. S. 2020. Adulteration and Bacterial Contamination of Locally Processed Honeys Marketed at Lafia Metropolis, Nasarawa State, Nigeria. Int.J.Curr.Microbiol.App.Sci. 9(07): 2488-2498. doi: https://doi.org/10.20546/ijcmas.2020.907.292 